\title{
Pentingnya pelestarian naskah kuno sebagai warisan budaya bangsa
}

\section{Sahidi}

\begin{abstract}
As one of the written historical evidence, ancient manuscripts or manuscripts are ancestral heritage that is rich in cultural values, moral values, religious values, and social values. The ancient manuscript also describes the previous human civilization that was rich in science. The ancient manuscript is a historical reminder that should be preserved and its existence is preserved so that the next generation of the nation can also recognize the values of the information contained in the text. Preservation is the most appropriate way to maintain the existence of ancient manuscripts from obliteration. Preservation efforts are activities carried out to preserve the heritage of cultural heritage in this case the ancient manuscripts so that they are not quickly damaged and can be used in accordance with the original. This is very important to be carried out by the relevant institutions to save the priceless national assets that have so far been neglected and are still very concerning. Along with the development of increasingly sophisticated technology, preservation also undergoes a change of method, from traditional to modern techniques. This method is the most appropriate method to do than traditional methods that can have an adverse effect on the manuscript, because there are many texts that have been physically damaged. With modern methods it is hoped that ancient manuscripts can be digitized so that they can be easily accessed and read by the next generation.
\end{abstract}

Keywords: preservation, ancient manuscripts, heritage, culture

\section{Pendahuluan}

Tradisi tulis Nusantara dengan serangkaian perjalanan panjangnya telah menghasilkan sedemikian banyak dokumen tertulis berupa naskah naskah kuno yang keberadaannya saat ini tersimpan di berbagai tempat koleksi, baik koleksi lembaga dan perorangan. Naskah naskah kuno tersebut sepatutnya harus dijaga keberadaannya dan dilakukan penelitian secara serius agar informasi penting yang terkandung di dalamnya dapat diketahui 
oleh semua orang, baik generasi saat ini maupun generasi yang akan datang.

Menurut Sudarsono (2009: 13) menyatakan bahwa Naskah kuno adalah darah kehidupan sejarah. Naskah tulisan tangan ini dapat dianggap sebagai salah satu representatif dari berbagai sumber lokal yang paling otoritatif dan paling otentik dalam memberikan berbagai informasi sejarah pada masa tertentu. Naskah kuno merupakan salah satu warisan budaya bangsa di antara berbagai artefak lainya, yang kandungan isinya mencerminkan masa lalu. Ditemukannya naskah kuno membuktikan perkembangan budaya literasi yang menjadi representasi dari berbagai sumber paling otentik dalam memberikan berbagai informasi sejarah pada masa tertentu.

Robson (1978) dalam Ikram, dkk (1981: 76) bahwa kandungan isi naskah beraneka ragam, misalnya alam pikiran, kepercayaan, sistem nilai yang turun-temurun, menunjukkan berbagai aspek kehidupan dan karya manusia yang khas bagi kelompok masing masing daerah. Naskah -naskah tersebut penting bagi pengetahuan kebudayaan daerah yang secara keseluruhan dapat memberikan gambaran mengenai kebudayaan nasional. Dengan kata lain, naskah merupakan sumber yang tak ternilai harganya bagi kebudayaan manusia Indonesia yang pada hakikatnya bersumber pada kebudayaan daerah.

Indonesia adalah salah satu negara pemilik naskah kuno (manuscript) terbesar di dunia, dengan tidak kurang dari 20 ragam bahasa lokal yang dipakai untuk menulisnya. Naskah kuno menjadi sumber primer yang mengandung sejarah kehidupan masyarakat Nusantara, serta banyak menjelaskan alasan mengapa kemudian terbentuk negara modern bernama Indonesia. Para Indonesianis Eropa, semisal Dennys Lombard, Anthony Johns, Edwin P Wieringa, Martin van Bruinessen, Henri Chambert-Loir, Willem van der Molen, Annabel Teh Gallop, Jan van der Putten, 
Peter Riddell, Michael Laffan, dan lainnya telah sering menunjukkan riset-riset untuk mengungkap sejarah dan faktorfaktor apa saja yang memberikan kontribusi terbentuknya wajah Indonesia hari ini. Sumber-sumber yang mereka pakai adalah manuskrip kuno berbahasa Melayu, Jawa, Arab, dan Belanda yang membentang dan tersedia sejak abad 16.( http://fah.uinjkt.ac.id/index.php/12-articles/features/14kurikulum-sejarah-dan-naskah-kuno ).

Sejarah telah menyadarkan kita betapa pentingnya dokumentasi dalam sebuah kehidupan. Secarik kertas tua berwarna kuning usang ternyata dapat menyiratkan segala peristiwa yang terjadi puluhan tahun silam. Melalui naskahnaskah kuno kita dapat mengetahui tentang apa yang terjadi di masa lampau. Sayang, kebanyakan naskah- naskah kuno berusia puluhan tahun tersebut kondisinya sungguh memprihatinkan. Tak jarang, tulisan- tulisan pada masa itu sudah pudar tidak terbaca. Ini belum termasuk tulisan- tulisan yang kertasnya mudah rapuh ketika dipegang. Peran pemerintah daerah (pemda) dalam pengumpulan dan pelestarian naskah kuno dinilai belum maksimal. Belum semua pemda mengalokasikan anggaran untuk proses itu. Kepala Pusat Preservasi Naskah Perpustakaan Nasional RI Sri Sumekar mengatakan daerah seharusnya mengalokasikan sejumlah dana untuk preservasi, pengumpulan, dan perawatan naskah kuno. Selain itu, anggaran dibutuhkan untuk melacak naskah-naskah yang dikuasai organisasi, kelompok, ataupun perorangan. (http://www.satuislam.org) Menurut Sumekar, saat ini, terdapat sekitar 9.000 ribu naskah kuno yang disimpan di Perpustakaan Nasional. Diperkirakan, masih ada sekitar satu juta naskah yang belum terdata di luar sana. Sri menjelaskan naskah kuno tidak boleh difotokopi karena kertasnya tua sehingga rentan rusak. Oleh karena itu, naskah dialihmediakan ke bentuk digital. Bentuk digital itu dapat dicetak dan difotokopi. 


\section{Pembahasan}

\section{a. Naskah Kuno}

Naskah kuno adalah naskah lama yang mengandung dua pengertian yaitu "naskah" dan " kuno atau lama". Naskah dalam bahasa inggris menuscrips, dalam bahasa latin manuscriptum dan dalam bahasa belanda Handschrift. Menurut Pudjiastuti (1996: 9) manuskrip merupakan bahan tulisan tangan yang menyimpan berbagai ungkapan rasa dan pikiran hasil budaya masa lampau, tetapi juga membuat unsur historis. Manuskrip adalah semua bahan tulisan tangan peninggalan nenek moyang yang tertulis pada kertas, lontar, kulit kayu, dan rotan. Berita tentang hasil budaya yang diungkapkan oleh teks klasik dapat dibaca dalam peninggalan-peninggalan berupa tulisan yang disebut manuskrip.

Naskah merupakan semua bentuk tulisan tangan berupa ungkapan pikiran dan perasaan sebagai hasil budaya bangsa pada masa lampau (Baried, 1985: 54). Menurut Undang-undang Republik Indonesia Nomor 43 Tahun 2007 Tentang Perpustakaan pada Pasal 1 Ayat 4 menyatakan bahwa naskah kuno adalah semua dokumen tertulis yang tidak dicetak atau tidak diperbanyak dengan cara lain, baik yang berada di dalam negeri maupun di luar negeri yang berumur sekurang-kurangya 50 (lima puluh) tahun, dan mempunyai nilai penting bagi kebudayaan nasional, sejarah dan ilmu pengetahuan. (Perpustakaan Nasional RI, 2008: 3)

Naskah yaitu karangan yang masih ditulis dengan tangan; karangan seseorang sebagai karya asli (KBBI, 1996). Naskah adalah benda peninggalan dalam bentuk tulisan tangan yang berisi berbagai aspek kehidupan yang dikemukakannya, misalnya masalah sosial, politik, ekonomi, agama, kebudayaan, bahasa, dan sastra. Apabila dilihat sifat pengungkapannya, dapat dikatakan bahwa kebanyakan isinya mengacu kepada sifat-sifat historis, 
didaktis, religius, dan belletri (Baried, 1985:56). Biasanya naskah ditulis oleh pengarangnya dengan berisikan hal-hal yang menjadi pengalaman dan imajinasinya dalam hidupnya sehari-hari. Seperti layaknya sebuah karya sastra, naskah juga kebanyakan merupakan karya sastrayang dip engaruhi oleh kehidupan sastra pada zaman itu. Selanjutnya menurut Baried (1985: 56) naskah itu dipandang sebagai cipta sastra karena teks yang terdapat dalam naskah itu merupakan suatu keutuhan dan mengungkapkan pesan. Pesan yang terbaca dalam teks secara fungsional berhubungan erat dengan filsafat hidup dan dengan bentuk kesenian yang lain.

Menurut Mamat (1988) di dalam bahasa Malaysia, perkataan naskhah digunakan dengan meluas sebelum perkataan manuskrip. Dalam bahasa Indonesia perkataan naskah lebih popular digunakan daripada kata-kata yang lainnya (manuskrip atau handschrift) karena kata naskah merupakan kata serapan dari bahasa Arab yang telah lama digunakan dalam bahasa Indonesia, bahkan penggunaannya sering diikuti dengan kata-kata lain seperti naskah pidato, naskah undang-undang, naskah perjanjian, naskah kerja sama, dan sebagainya sehingga dalam hal ini, arti kata naskah telah bergeser pada arti teks (Mulyadi, 1994: 3).

Berdasarkan pengertian tersebut, maka yang dimaksud dengan naskah kuno atau manuskrip adalah dokumen yang berbentuk apapun yang ditulis tangan atau diketik yang belum dicetak atau dijadikan buku tercetak yang berumur 50 tahun lebih dan memuat informasi-informasi penting yang dapat dijadikan sebagai sumber informasi primer.

\section{b. Kandungan Informasi dalam Naskah Kuno}

Naskah kuno sebuah bentuk peninggalan budaya yang sampai sekarang masih dapat dirasakan keberadaanya. Naskah 
kuno memiliki nilai informasi yang sangat berharga baik ditinjau dari aspek sejarah naskah tersebut. Menurut Munawar dan Noegraha (1997: 42), naskah kuno merupakan salah satu sumber informasi kebudayaan daerah pada masa lampau yang sangat penting. Apabila ditinjau dari segi lahir atau wujud yang dapat dilihat dan diraba, naskah kuno adalah benda budaya yang berupa hasil karangan dalam bentuk tulisan tangan atau ketikan, namun bukanlah kumpulan tulisan yang tanpa makna. Dalam naskah-naskah tersebut terkandung berbagai gagasan, pendapat, pengertian, perasaan, pengalaman jiwa dan pandangan hidup yang meliputi berbagai aspek kehidupan manusia. Peninggalan suatu kebudayaan yang berupa naskah merupakan dokumen bangsa yang paling menarik, karena memiliki kelebihan yaitu dapat memberi informasi yang lebih luas. Kandungan isi naskah beraneka ragam, misalnya alam pikiran, kepercayaan, sistem nilai yang turun temurun, menunjukan berbagai aspek kehidupan dan karya manusia yang khas bagi kelompok masing-masing daerah. Naskah-naskah tersebut penting bagi pengetahuan kebudayaan daerah yang secara keseluruhan dapat memberikan gambaran mengenai kebudayaan nasional. Naskah kuno merupakan sumber yang tak ternilai harganya bagi kebudayaan manusia Indonesia yang ada hakikatnya bersumber pada kebudayaan daerah. (Achadiati, 1997: 76)

Naskah-naskah kuno perlu untuk dilestarikan kebudayaanya agar tidak musnah dan bermanfaat bagi kehidupan masyarakatnya. Upaya melestarikan bisa dilakukan melalui penyimpanan di museum atau di perpustakaan serta mengelola dengan mengkaji isi yang terkandung di dalamnya agar mudah dipahami dan dimanfaatkan oleh pengembang kebudayaan. Peninggalan-peninggalan naskah pada masa lampau banyak yang tersebar di wilayah jawa. Sebagian besar telah dihimpun dalam koleksi naskah lembaga ilmiah seperti: Perpustakaan Museum 
Sonobudoyo Yogyakarta, Perpustakaan Pura Pakualam Yogyakarta, Perpustakaan Museum Radya Pustaka Surakarta, Perpustakaan Reksa Pustaka Mangkunegara Surakarta, serta naskah-naskah koleksi pribadi yang tersebar luas di segala lapisan masyarakat.

\section{c. Pelestarian (Preservasi)}

Pemeliharaan koleksi atau naskah kuno menurut Rahayuningsih (2007: 130-136) meliputi 3 kegiatan, yaitu pelestarian, pengawetan dan perbaikan :

1) Pelestarian (preservation): pelestarian koleksi adalah kegiatan yang dilakukan untuk mempertahankan koleksi agar dapat digunakan dalam jangka waktu yang lama. Tidak setiap perpustakaan harus melakukan kegiatan pelestarian koleksi dalam bentuk aslinya, tergantung pada jenis, tujuan dan fungsi perpustakaan. Suatu perpustakaan mungkin hanya menyimpan koleksi terakhir atau hanya menyimpan bentuk mikro atau fotokopinya saja, sehingga hanya melakukan pengawaten tanpa harus melakukan pelestarian. Bentuk pelestarian bahan pustaka misalnya adalah fotokopi, mikrofilm, mikrofis, filmstrip, slide, CD-ROM.

2) Pengawetan (conservation): Pengawetan koleksi adalah kegiatan yang dilakukan untuk melindungi koleksi dari kerusakan dan kehancuran. Koleksi yang terbuat dari kertas merupakan bahan yang mudah terbakar, mudah rusak karena dimakan serangga, terkena noda, debu dan jamur. Oleh karena itu, koleksi perlu dilindungi dengan cara membersihkan debu, mengadakan pengasapan untuk membunuh serangga dan jamur, dan menghilangkan noda. Pengawetan perlu dilakukan secara rutin agar informasi yang terdapat di dalam koleksi selalu terjaga dengan baik dan utuh. 
3) Perbaikan (restoration): Perbaikan koleksi adalah kegiatan yang dilakukan untuk memperbaiki koleksi yang rusak sehingga dapat digunakan lagi. Perbaikan koleksi meliputi kegiatan penjilidan, perbaikan punggung buku yang rusak, perbaikan halaman buku yang rusak, perbaikan halaman yang lepas, penyampulan bahan pustaka.

\section{d. Digitalisasi Naskah Kuno}

Dalam upaya penyelamatan naskah-naskah kuno (Preservasi), dapat dilakukan dalam berbagai cara seperti konservasi, restorasi dan pembuatan salinan (Backup). metode yang cukup efektif adalah metode ke-tiga dengan membuat salinan (backup) sehingga dapat mengurangi ketergantungan untuk langsung mempelajari pada naskah asli yang berpotensi mempercepat kerusakan naskah akibat faktor-faktor luar seperti udara dan cairan keringat yang mengandung asam. proses pembuatan salinan dengan pembuatan microfilm mulai dikembangkan mulai tahun 1980-an sampai akhir tahun 1990-an. ketika dunia teknologi mulai bergeser ke era digital, Penggunaan teknologi microfilm mulai bergeser ke digitalisasi sebagai upaya preservasi naskahnasakah kuno seperti dengan cara foto kamera ataupun scanning naskah, karena dinilai lebih mudah, baik dalam pembuatan, penyimpanan, maupun pengunaan dan akses informasinya. (ttp:/ / regional.kompasiana.com/2010/10/15/menyelamatkannaskah-kuno-koleksi-museum-radyapustaka-solo-290752)

Saat ini sudah banyak koleksi nasakah yang sudah didigitalkan dan dapat diakses melalui media-media online seperti perpustakaan digital yang sudah di release oleh beberapa lembaga baik lembaga pemerintahan maupun lembaga pendidikan. hal yang perlu diperhatikan adalah peranan dari Perpustakaan Nasional RI dan Badan Arsip Nasional sebagai lembaga pemerintah agar seyogyanya lebih berperan aktif dalam upaya preservasi naskah-naskah kuno 
Preservasi digital adalah kegiatan yang terencana dan terkelola untuk memastikan agar bahan digital dapat terus dipakai selama mungkin. Preservasi digital juga upaya memastikan agar materi digital tidak tergantung pada kerusakan atau perubahan teknologi. Maka dapat disimpulkan bahwa preservasi digital mencangkup berbagai bentuk kegiatan, mulai dari kegiatan sederhana menciptakan tiruan (rublika atau copy) dari sebuah mater digital untuk disimpan sampai kegiatan tranformasi digital yang cenderung rumit. Kegiatan ini didasarkan pada penilaian tentang penting tidaknya materi yang akan dipreservasi, dan seberapa besar resiko kerusakan yang diperkirakan akan terjadi pada materi yang bersangkutan, biasanya kegiatan prservasi digitla dilakukan oleh institusi yang peduli terhadap nilai penting materi digital yang mereka miliki, dan karena itu materi tersebut harus tetap dapat diakses dan digunakan selama mungkin. Seluruh hasil kegiatan prservasi ini kemdian disimpan secara khusus dan dapat menjadi apa yang disebut institutional repository atau simpanan kelembagaan. (Pendit, 2008: 248).

\section{e. Pelestarian Bahan Pustaka di Indonesia dan Kendalanya}

Secara tradisional pelestarian bahan pustaka telah lama dilakukan di Indonesia. Pada berbagai kraton, para penjaga menyalin naskah lama ke naskah baru dengan menggunakan bahan tulis tradisional berupa daun lontar. Ketika perpustakaan mulai berkembang maka penjilidan buku dan majalah mulai dilakukan.

Dengan perkembangan teknologi informasi, khususnya mikrofilm, maka mulai banyak bahan pustaka Indonesia yang dibuatkan mikrofilm. Proses alih bentuk ini banyak dibantu oleh lembaga asing, terutama dalam bantuan peralatan, tenaga dan dana. Sekitar tahun 1970-an, Koninlijk Instituut voor Taa-, Land-en Volkenkunde (KITLV) berkerjasama dengan Lembaga Ilmu Pengetahuan Indonesia (LIPI) mulai membuat mikrofilm setiap 
buku yang dibeli oleh KITLV. Buku yang dibeli lazimnya buku bidang ilmu sosial dan budaya. Mikrofilm diserahkan pada LIPI sementara induk mikrofilm disimpan KITLV. Berbagai naskah di Sulawesi Selatan, dikenal dengan nama lontara dibuatkan mikrofilm dengan bantuan Australia. Naskah kuno yang terdapat di kraton Mangkunegoro, Kasunanan (Surakarta), Kesultanan Yogyakarta, serta Pakualaman juga dibuatkan mikrofilm, dengan bantuan Rockefeller Foundation (Sulistyo-Basuki, 1991: 278). Menurut Sulistyo-Basuki, 1991: 279) bahwa pelestarian dan pengawetan bahan pustaka mengalami banyak kendala seperti:

1. Kurangya tenaga pelestarian di Indonesia. Hingga kini belum ada lembaga pendidikan yang mengkhususkan diri pada pelestarian serta belum jelas apakah untuk tenaga pelestarian diperlukan pada tingkat teknis atau tingkat profesional.

2. Banyak pimpinan serta pemegang kebijakan belum memahami pentingnya pelestarian sehingga mengakibatkan kurangya dana, perhatian, dan fasilitas yang tersedia.

3. Praktik pelestarian yang dilakukan selama ini di Indonesia masih banyak yang salah. Sebagai contoh penggunaan celotape tidak selalu dapat memperbaiki bahan pustaka malahan sering kali merusak bahan pustaka karena komposisi kimiawinya merusak kertas.

4. Berbagai bahan pustaka yang disimpan di Perpustakaan Indonesia tercetak dalam kertas yang beraneka warna mutunya. Justru banyak bahan pustaka dari periode Perang Kemerdekaan dicetak dalam kertas sejenis kertas merang yang kurang baik mutunya, namun tinggi nilai historisnya.

5. Berbagai ruang perpustakaan tidak dirancang bangunan yang sesuai dengan keperluan pelestarian dan pengawetan. Masih banyak ruang perpustakaan menerima sinar matahari secara langsung sehingga mempercepat proses kerusakan bahan pustaka. 
6. Pada tingkat nasional belum terdapat kebijakan pelestarian nasional. Kebijakan ini merupakan hasil kerja bersama antara berbagai instansi terkait

\section{Kesimpulan}

Naskah kuno merupakan warisan dari nenek moyang bangsa Indonesia yang di dalamnya mencerminkan keperibadian dan budaya bangsa yang luhur. Naskah kuno merupakan peniggalan sejarah yang sepatutnya dijaga dan tetap dilestarikan keberadaanya agar generasi penerus bangsa juga dapat mengenal nilai-nilai informasi yang terdapat pada naskah tersebut. Pelestarian (preservation) merupakan cara yang paling tepat untuk mempertahankan keberadaan naskah kuno dari kemusnahan. Upaya pelestarian merupakan kegiatan yang dilakukan untuk mempertahankan peninggalan cagar budaya dalam hal ini naskah kuno agar tidak cepat rusak dan dapat digunakan sesuai dengan aslinya. Hal ini sangat penting dilakukan oleh institusi terkait untuk menyelamatkan aset bangsa yang tak ternilai harganya yang selama ini memang kurang dan masih sangat memprihatinkan keberadaanya.

Seiring dengan perkembangan teknologi yang semakin canggih, pelestarian juga mengalami perubahan metode, dari yang tradisional hingga ke teknik modern yang dibantu dengan mesin. Metode ini merupakan metode yang paling tepat dilakukan daripada metode tradisional yang dapat berdampak tidak baik terhadap nasakah tersebut, dikarenakan banyak naskah yang memang sudah rusak fisiknya. Dengan metode modern diharapkan naskah kuno dapat digitalisasi sehingga dapat dengan mudah diakses dan dibaca oleh generasi berikutnya.

\section{Daftar Pustaka}

Basuki, Sulistyo. (1991). Pengantar Ilmu Perpustakaan. Jakarta: PT. Gramedia Pustaka Utama. 
Baroroh Baried, Siti. (1985). Pengantar Teori Filologi. Jakarta: Pusat Pembinaan dan Pengembangan Bahasa. Departemen Pendidikan dan Kebudayaan.

http://regional.kompasiana.com/2010/10/15/menyelamatkannaskah-kuno-koleksi-museum-radyapustaka-solo290752.html akses tanggal 6 November 2014 pukul 09.00 wib.

http://fah.uinjkt.ac.id/index.php/12-articles/features/14kurikulum-sejarah-dan-naskah-kuno akses tanggal 6 Desember 2014 pukul 10.00 wib.

http://www.satuislam.org/humaniora/banyak-naskah-kunotercecer-dan- tidak-terdata/ akses tanggal 6 Desember 2014 pukul 10.30 wib.

Ikram, A. Dkk. (1981). Filologi Nusantara. Jakarta: Pustaka Jaya.

Laxman Pendit, Putu. (2008). Perpustakaan Digital dari A sampai $Z$, Jakarta: Citra Karyakarsa Mandiri.

Perpustakaan Nasional RI. (2008). Undang-undang Republik Indonesia Nomor 43 Tahun 2007 Tentang Perpustakaan, Jakarta: Perpustakaan Nasional RI.

Pudjiastuti, Titik. (1996). Analisis Unsur Sejarah Dalam Sumber Tertulis Cirebon. Depok: FSUI.

Rahayuningsih. (2007). Pengelolaan Perpustakaan. Yogyakarta: Graha Ilmu.

Sudarsono, Blasius. (2009). Pustakawan Cinta dan Teknologi. Jakarta: ISIPII.

Tuti Munawar dan Nindya Noegraha. (1997). Khasanah Naskah Nusantara dalam tradisi tertulis di Indonesia. Jakarta: Masyarakat Pernaskahan Nusantara.

Mulyadi, Sri Wulan Rujiati. (1994). Kodikologi Melayu di Indonesia,Lembar Sastra Edisi Khusus No. 24. Depok: Fakultas Sastra Universitas Indonesia. 